\title{
O texto literário como corpus para análise lexical: $O$ Púcaro Búlgaro, de Campos de Carvalho
}

\author{
Caio Santilli Oranges \\ Universidade Estadual Paulista "Júlio de Mesquita Filho" (UNESP), \\ Araraquara, São Paulo, Brasil \\ csantillioranges@gmail.com
}

DOI: http://dx.doi.org/10.21165/el.v46i1.1568

\begin{abstract}
Resumo
O universo de discurso literário engloba um sem-número de outros universos de discurso, transformando-o em um rico e frutífero ambiente para análises linguísticas, sobretudo no nível lexical. Este trabalho, portanto, de caráter modelar, tem como objetivo demonstrar de que maneiras o texto literário se apresenta como corpus para uma análise linguística. Por trabalhar com a arte, além da comunicação, o autor literário deve sempre objetivar a expressividade no uso da língua. É o que tentaremos demonstrar, utilizando como exemplo o romance $O$ Púcaro Búlgaro, de Campos de Carvalho, uma narrativa composta, essencialmente, pela denúncia, renúncia e afastamento das questões de ordem lógica do mundo histórico e social. Para isso, o presente artigo retoma conceitos gerais a respeito da lexicologia e lexicografia, resume questões gerais a respeito do texto literário, e revisa alguns dos principais estudos recentes que trabalharam essa interface. Ao final, são apresentados modelos de análise lexical com a obra literária supracitada.
\end{abstract}

Palavras-chave: texto literário; léxico; O Púcaro Búlgaro.

\section{The literary text as a corpus for lexical analysis: $O$ Púcaro Búlgaro by Campos de Carvalho}

\begin{abstract}
Many discourse universes are included in the literary discourse universe, converting it into a rich and productive environment for linguistics, mainly for lexicon analysis. Therefore, this experimental paper aims to show in which ways a literary text presents itself as a corpus for linguistic analysis. Because it has the influence of art, aside from communication, the literary author must always intent language's biggest expressiveness. That is what we will try to demonstrate, using a Brazilian novel by Campos de Carvalho, called O Púcaro Búlgaro as an example. The main characteristics of this novel are the distance, resignation and removal from all logic aspects that make life something ruled. Thus, this paper takes back general concepts about lexicology and lexicography, and summarizes aspects about the literary text. It also reviews some of the most recent works on this area. Finally, it presents some examples of how to make a lexical analysis using a literary text.
\end{abstract}

Keywords: literary text; lexicon; O Púcaro Búlgaro.

\section{Introdução}

Os universos de discurso são domínios de reconhecimento ideológico e, sobretudo, de produção de sentido. Existem variados universos, e é possível depreender inúmeras questões socioculturais de uma determinada sociedade a partir do seu uso discursivo. Além disso, cada universo de discurso é marcado por uma determinada norma 
que o caracteriza, e essa norma se reflete nos mais diversos níveis linguísticos, dentre eles o lexical.

Segundo Dubois et al. (2014, p. 566), os universos discursivos são definidos como: "o mínimo irredutível de contexto necessário a um enunciado [...] é a própria condição, original, da produção do enunciado, ou melhor, é o que o torna possível". Assim, o universo que engloba o texto literário é extremamente produtivo, visto que nele se reúnem outros tantos universos encontrados na sociedade. Enquanto o discurso do cotidiano objetiva a comunicação, através da correspondência das coisas em signos, o discurso literário "é um objeto da linguagem ao qual se associa uma representação de realidades físicas, sociais e emocionais mediatizadas pelas palavras da língua na configuração de um objeto estético" (PROENÇA FILHO, 2007, p. 7).

Do mesmo modo, a literatura, por excelência, é um repositório linguístico frutífero de produção de sentido. O autor desse tipo de texto almeja, a todo momento, a exteriorização da vivacidade no uso da língua, imprimindo recursos que conferem credibilidade e sentimento de inovação. E é por meio do léxico que esses processos são construídos, seja através da inovação lexical (neologismos) ou do uso linguístico mais eloquente, o texto literário revela um modelo particular: "Este discurso literário [...] obedece, na maioria das vezes, ao discurso comum, mas diferencia-se deste, na medida em que o significante se apaga para poder sobressair o significado" (MARTINS, 2007, p. 69).

Este trabalho, portanto, de caráter modelar, tem como objetivo principal evidenciar de quais formas o texto literário, construído por intermédio de uma linguagem que, ao mesmo tempo, se aproxima e se distancia da linguagem comum, pode se apresentar propício para uma análise lexical. Para tal, utilizamos como exemplo a obra $O$ Púcaro Búlgaro, escrita pelo autor mineiro Walter Campos de Carvalho, e publicada em 1964. Pautada sobre os pilares da loucura e do nonsense, O Púcaro Búlgaro retrata a vida de um grupo de expedicionários que têm como propósito organizar uma viagem à Bulgária, a fim de atestar a existência desse país e, principalmente, dos Púcaros Búlgaros.

Dessa forma, a seção 2 apresenta conceitos básicos a respeito de duas ciências do léxico as quais já se apresentaram capazes de abordar o texto literário: a lexicologia e a lexicografia. Ainda nessa seção, trata-se da questão da construção e produção de sentido no texto literário e como isso ocorre. Por fim, discute-se pontos em comum entre as ciências do léxico supracitadas e o texto literário.

Na seção 3, são apresentados alguns trabalhos que já trataram a interface léxico e literatura, e os resultados a que chegaram tais produções. São discutidas questões como o neologismo literário e os dicionários de especialidade. A seção 4, por sua vez, traz os exemplos retirados da obra $O$ Púcaro Búlgaro e possíveis abordagens lexicais para um texto literário. A quinta e última seção, por fim, conclui esse trabalho, de modo a sugerir o quão produtivo pode ser um texto literário para uma análise linguística. 


\section{O léxico e o texto literário}

\subsection{A lexicologia}

O léxico é o nível linguístico mais instável, aberto e suscetível às alterações sociais, visto que ele está diretamente relacionado com a cultura e a sociedade. É através do léxico que as crenças e os costumes de uma sociedade se materializam. Toda a visão de mundo de um povo é manifestada no e pelo léxico. Em outras palavras, o léxico de uma língua reflete a cultura e os hábitos de uma sociedade, tornando-se um espelho desta. Assim, coadunamos com Biderman (1978, p. 139) quanto ao conceito de léxico: "Qualquer sistema léxico é a somatória de toda a experiência acumulada de uma sociedade e do acervo da sua cultura através das idades".

Divide-se, tradicionalmente, os Estudos do Léxico em três diferentes ciências: lexicologia, lexicografia e terminologia. Para os fins deste trabalho, apenas a primeira será esclarecida, por já ter se mostrado suficientemente produtiva para um trabalho consistente com o texto literário.

Dessa forma, a lexicologia é a ciência que estuda o léxico por excelência, e as unidades que o compõem, isto é, as palavras. O conceito de palavra é ainda impreciso, visto que engloba um sem-número de dificuldades. A depender da abordagem que se confere, a delimitação da palavra será um problema. Conforme afirma Biderman (1999, p. 82): "[...] o conceito de palavra não pode ter um valor absoluto; ele é relativo e varia de língua para língua".

Os estudos em lexicologia são geralmente voltados à questão do signo linguístico, conforme proposto por Saussure e aperfeiçoado posteriormente. Por falar em Saussure, a vertente estruturalista, que teve seu início com as publicações do linguista genebrino, não considerava o léxico como um sistema passível de estudo, visto que esse era considerado apenas uma lista das irregularidades, mas não um sistema. Isso explica o fato de a lexicologia ter tido certo atraso para ser estudada, se comparada à lexicografia.

A questão do significado das palavras e dos processos de formação delas são temas que interessam à lexicologia, sendo constantemente objeto de estudo dessa área. Além disso, alguns estudos tratam de questões como a estruturação do léxico e a descrição das estruturas morfossintáticas e semânticas, os campos semântico-lexicais de palavras e suas relações, a inovação lexical por meio de neologismos, entre outras.

De forma geral, a lexicologia é a ciência que se ocupa do léxico, buscando dar conta de sua organização, estruturação e sistematização através dos tempos.

\subsection{A construção de sentido no texto literário}

A língua é um sistema aberto e heterogêneo, que está sempre disponível para a comunicação de seus usuários e para a veiculação de emoções e informações. Quando utilizada em universos de discurso específicos, como as linguagens técnico-científicas, a língua revela quais os mecanismos linguísticos mais eficazes para aquele caso de criação, inovação ou expressividade vocabular. Cada universo de discurso possui traços linguísticos específicos que o caracterizam, sendo que alguns traços podem ser comuns a mais de um universo.

Ao ser empregado no universo literário, no entanto, nem sempre existirá uma regra para que determinado recurso linguístico seja o mais utilizado. Isso porque os textos 
literários abrangem particularidades de diversos universos, pertencentes às diversas esferas de conhecimento. Do mesmo modo, nenhum texto literário é igual a outro, visto que autores diferentes utilizam artifícios diferentes, no intuito de cumprirem com os objetivos de sua obra/estilo ou escola literária.

Por essa razão, Barbosa (2001, p. 34) afirma: “[...] parece pouco produtivo avaliar a questão [dos recursos utilizados na linguagem literária] no conjunto das obras. Há que considerá-la em cada obra manifestada". É o que objetivamos fazer neste trabalho, utilizando exemplos de O Púcaro Búlgaro, obra escrita por Campos de Carvalho.

Apesar das dificuldades de se definir precisamente as características do discurso literário, não é surpresa que a linguagem utilizada nele carregue algo além do usual, no que tange à significação: "já se percebe o alto índice de multissignificação dessa modalidade da linguagem que, de antemão [...] sabemos ser especial e distinta da modalidade própria do uso cotidiano" (PROENÇA FILHO, 2007, p. 8).

A norma que preside o texto literário é a retórica, diferentemente dos discursos ordinários, os quais têm como guia a comunicação. Isso ocorre já que, além de comunicar, o discurso literário objetiva também encantar e narrar uma história, a fim de prender o leitor. Neste universo de discurso, portanto, co-ocorrem a arte, a informação e a comunicação. Conforme Proença Filho (2007, p. 42): "o texto literário é, ao mesmo tempo, um objeto linguístico e um objeto estético".

A fim de cumprir esses objetivos, os autores literários lançam mão de diversos recursos linguísticos, os quais se manifestam no nível do léxico, como a inovação lexical, a mudança de significado, inversões sintáticas, mudança de função sintática, entre outras. Dessa forma, o que ao leitor parece uma transgressão à norma da língua é, na verdade, um recurso estilístico empregado pelo autor do texto.

Por essas razões, sobrelevamos o fato de as unidades lexicais não serem compreendidas de acordo com o significado delas no mundo em outros universos discursivos. Em outras palavras, o entendimento do sentido das palavras deverá se dar apenas pelo significado que elas possuem no contexto da obra, pois é nesse contexto que elas emergem. A esse respeito, Proença Filho (2007, p. 74-75) afirma: "o referente se liga ao contexto extraverbal; se situaria, portanto, fora da linguagem; o sentido das palavras, no texto literário, emerge do próprio texto e se apoia sobretudo na dimensão conotativa".

Posto que o universo de discurso literário é próprio, diferente do mundo comum, e sua linguagem é característica, a fim de atender aos propósitos da obra, as unidades que compõem esse discurso devem também ser entendidas da mesma forma, isto é, no contexto de produção da obra, segundo as características do autor, de seu estilo literário, de sua escola, ou de qualquer outro fator que influencie sua escrita. Dessa forma, uma unidade lexical que transgrida o sistema linguístico, ou que seja utilizada com significado diferente do comum, é motivada por uma série de fatores da própria obra literária que o justificam: "no interior do texto literário, é estabelecida uma rede semântica envolvendo os significados de todas as palavras empregadas" (ALVES, 2013, p. 91). 


\subsection{A interface léxico-literária}

Após uma breve explicação a respeito das ciências do léxico que mais têm se aproveitado da linguagem literária, e de entendermos sucintamente de que forma esse universo do discurso funciona, vamos agora buscar entender quais aspectos lexicais têm sido mais abordados em textos literários em geral.

Como explicado na seção anterior, é difícil afirmar quais aspectos são realmente próprios da linguagem da literatura. Isso se deve ao fato não apenas de esse universo tirar proveito de outros tantos universos mais usuais, mas também pelo fato de, dentro do próprio universo literário, existir uma gama enorme de características de determinada escola, obra ou autor. Segundo Proença Filho (2007), os estudiosos e pesquisadores do discurso literário têm encontrado um grande desafio para definir as especificidades desse discurso.

Ainda assim, o que se observou, ao consultar trabalhos que envolveram a interface léxico-literária, é que o principal recurso linguístico abordado é a inovação lexical ou neologismo. Neologismos são unidades lexicais inéditas, que não fazem parte do léxico de uma língua, e que foram criadas segundo processos morfossintáticos ou semânticos, ou que foram adotados de línguas estrangeiras, os chamados empréstimos linguísticos.

Além disso, conforme afirmamos no item 2.2, as unidades lexicais e seus significados devem sempre ser depreendidos do contexto da obra, buscando amparo em questões como o estilo do autor, a escola literária etc. Conforme afirma Alves (2013, p. 88):

No caso das formações neológicas no texto literário, somente a verificação da relação estabelecida entre o significante e o significado não é suficiente para sua interpretação, sendo preciso, no entanto, ir além da individualização do novo signo, o que significa que a inserção de uma nova forma em determinada obra literária responde à criatividade do seu criador (o autor) de determinar a expressividade do texto.

Isso ocorre devido ao fato de o discurso literário ser muito impreciso, visto que ele pode envolver "adesão, transformação ou ruptura em relação à tradição linguística" (PROENÇA FILHO, 2007, p. 46), sendo sua linguagem totalmente definida pela criatividade do autor. É usual a criação de novas formas de se expressar, refletidas no léxico, que deem conta de expressar exatamente o que pretende o artista. Dito de outro modo: "não existe uma 'gramática normativa' para o texto literário. Seu único espaço de criação é o da liberdade" (PROENÇA FILHO, 2007, p. 46).

Enfim, de forma geral, foi possível observar que os estudos lexicais que se detiveram sobre o texto literário focalizaram a questão do neologismo, por ser esse um campo produtivo e frutífero, principalmente em textos do universo literário, tendo em vista que a linguagem desse universo é das mais expressivas, pelos motivos já elencados anteriormente. No entanto, outros autores já se dedicaram a processos diversos, conforme se verá na seção a seguir. 


\section{Revisando trabalhos sobre léxico e literatura}

Um trabalho de análise linguística, no nível lexical, que tenha como corpus um texto literário deve levar em conta todos os fatores supracitados na seção 2. Dessa forma, o pesquisador que volte sua atenção aos aspectos lexicais de determinada obra ou autor literário deverá necessariamente observar qual processo ou fenômeno linguístico é mais recorrente nessa obra ou autor antes de definir o que será analisado. Dito de outro modo, a definição do fenômeno a ser observado na obra ou autor em questão não pode ocorrer sem uma prévia observação ou conhecimento a respeito do estilo e da construção do texto literário a ser estudado.

Não faria sentido, por exemplo, um estudo que buscasse atestar os neologismos cunhados por um autor que não utiliza esse recurso para a construção de seu texto, bem como não caberia uma análise de um vocabulário ou campo lexical em uma obra que não o explora. Isso posto, revisamos, nesta seção, alguns trabalhos mais recentes que têm abordado a interface entre léxico e literatura.

O primeiro trabalho a que tivemos acesso é o de Martins (2008), intitulado $O$ Léxico de Guimarães Rosa. Este trabalho, apresentado na forma de um dicionário de especialidade, insere-se no campo da lexicografia literária, e reúne 8.000 palavras, das quais mais de $30 \%$ não eram dicionarizadas, retiradas de 11 obras de Guimarães Rosa. Segundo a autora:

A linguagem intensamente elaborada de Guimarães Rosa foge, intencionalmente, à transparência para se embeber de mistério. Há obstáculos que exigem a atenção e provocam reação diversa nos leitores. A sintaxe, por suas inversões e elipses, e o léxico, por sua requintada complexidade, não permitem que o texto seja recebido passivamente, mas solicitam o leitor a ter também algum papel na criação artística. (MARTINS, 2008, p. 9).

O uso linguístico da obra rosiana é composto por neologismos, regionalismos, arcaísmos e muitos outros fenômenos linguísticos que fazem do vocabulário dessas obras um dos mais vastos e ricos na literatura brasileira. $\mathrm{O}$ autor, movido pela imaginação, sensibilidade e conhecimento acerca da língua, buscava a perfeição em seus escritos, sendo necessário utilizar as potencialidades da língua, desafiando o leitor, em busca da maior expressividade, afirma Martins (2008).

O trabalho dessa autora engloba as unidades lexicais de maior valor estilístico nas obras selecionadas de Guimarães Rosa, e abriu margem para muitas descobertas lexicais: "Muitas vezes imagina-se serem de sua criação palavras que se desconhecem, que são, contudo, arcaísmos, regionalismos, indigenismos ou neologismos já empregados por outros" (MARTINS, 2008, p. 10).

O segundo trabalho que foi observado e chamou a atenção foi o de Martins (2004). Neste, o autor tem como objetivo analisar o vocabulário e a criatividade de Millôr Fernandes, escritor brasileiro que, por meio dos neologismos, expressava humor e brincava com as palavras. Conforme afirma o autor deste estudo: "O que chamava a atenção não era o processo de formação de palavras [...]. Humorista, Millôr brincava com as palavras criando um dicionovário [novo dicionário]” (MARTINS, 2004, p. 60).

Alguns dos exemplos apresentados demonstram que Millôr Fernandes criou uma norma própria, de forma a suprir as necessidades expressivas que almejava em sua obra. 
Muitos desses neologismos são palavras já existentes na língua, que tiveram uma nova acepção embutida pelo autor através do uso. Outras, por sua vez, eram inovações possíveis, isto é, permitidas pelo sistema linguístico e possíveis de serem criadas a qualquer momento. De maneira geral, Martins (2004) concluiu que o léxico milloriano é próprio desse autor, difícil de ser empregado de forma tão natural por qualquer outra pessoa, seja em um texto literário ou não.

O mesmo pesquisador ainda publicou um outro estudo em 2007, o qual trata a criação de neologismos na obra poética de Cruz e Sousa. Este trabalho utiliza tal autor literário de forma a analisar as criações lexicais pertencentes ao Simbolismo, visto que essa escola "vai pesquisar os processos de criação lexical para formar um léxico neológico próprio para suas necessidades estéticas" (MARTINS, 2007, p. 67). Assim, para conseguir exteriorizar a fuga do mundo real e consciente, usa-se a língua como objeto estético.

O trabalho focaliza o estudo neológico, situando-se na relação da literatura com a lexicologia. O resultado do estudo observou grande incidência de substantivos, compostos, adjetivos, verbos e advérbios neológicos de autoria cruzesousiana. No entanto, a análise se deteve aos substantivos, de forma a analisar morfemas derivacionais. Concluiu-se, portanto, que a sufixação é um processo muito produtivo e deveras utilizado pelo poeta brasileiro.

Outro trabalho interessante é o de Ávila e Martins (2008), o qual estudou o léxico indianista na obra do romancista brasileiro José de Alencar. A prosa alencariana é marcada pela busca da identidade brasileira, e o autor encontrou nas línguas indígenas a forma de mostrar isso, escrevendo três romances cuja abordagem retratava o índio: Iracema, $O$ Guarani e Ubirajara. A esfera da escola romântica pós colonização portuguesa dominava o pensamento dos autores literários da época, e foi na figura de José de Alencar que isso se revelou.

Por essa razão, o estudo de Ávila e Martins (2008) é muito proveitoso, justamente porque revela como a busca pela identidade brasileira por meio dos indígenas é revelada no léxico utilizado pelo romancista brasileiro. A análise encontrou 168 palavras cuja "roupagem" era indianista. Como afirmam os autores, alguns dicionários utilizados como filtro apresentam as unidades lexicais de origem indígena apenas por elas terem sido utilizadas nas obras alencarianas, visto que estas foram usadas na montagem dos dicionários.

De modo geral, os autores concluíram que o léxico indianista é amplamente usado por Alencar, de forma a construir o sentido de suas obras coerentemente com suas propostas. Além disso, o autor muitas vezes mistura a língua tupi com a portuguesa, formando palavras novas. Ávila e Martins (2008) concluíram também que não há coerência entre os dicionários tupis, pois muitas unidades possuem significados distintos de um para outro.

O trabalho de Alves (2013), por sua vez, estuda os poemas publicados por João Cabral de Melo Neto, autor brasileiro do século XX. A análise chama a atenção visto que a autora investiga a inovação lexical implementada pelo escritor através de palavras compostas e fraseologismos, propondo um estudo por meio da coindexicação semântica. É uma análise, de certa forma, inovadora, visto que o trabalho com o léxico por meio da literatura, principalmente quando se trata de neologismos, busca evidenciar os fenômenos linguísticos mais usuais, como o processo de derivação. 
A autora, no entanto, propõe um outro tipo de análise, levando em conta sempre o estilo modernista de Melo Neto, característico de seu tempo. Segundo ela:

No contexto literário, as criações respondem às exigências expressivas do enunciador. Para isso, ele recorre aos elementos de sua língua e escolhe aqueles recursos que melhor atendem sua necessidade de expressão. Logo, nota-se que o processo de criação está ligado a algo pessoal, individual, a um ato de escolha, ou seja, está intimamente relacionado ao estilo do poeta (ALVES, 2013, p. 90).

Dessa forma, a autora justifica a análise que empenha sobre os compostos e os fraseologismos da obra poética de João Cabral de Melo Neto, recursos linguísticoexpressivos recorrentes nas produções do escritor.

Por fim, o estudo empreendido por Franco (2008) é outro que julgamos considerável, visto que o autor foge aos padrões de estudos léxico-literários. O trabalho do pesquisador é sobre os empréstimos e estrangeirismos adotados na língua portuguesa por meio da obra do escritor brasileiro João do Rio. Franco (2008) pesquisa como os termos provindos de outra língua e utilizados pelo escritor foram incorporados ao vocabulário do final do século XIX e início do XX, época da Belle Époque, na qual o Rio de Janeiro sofreu muita influência social e cultural advinda da França.

Dessa forma, os poemas do carioca João do Rio incorporavam esse vocabulário de ascendência europeia, notadamente francesa e inglesa. A população do Rio de Janeiro, por sua vez, na ânsia de copiar os costumes europeus, aceitou facilmente esses estrangeirismos. Segundo o autor:

[...] a cidade e a sociedade adotaram o espírito francês da Belle Époque, como frequentar salões, óperas, consumir mercadorias de luxo, em suma, todos os usos e costumes da alta sociedade francesa. [...] a elite renegou o passado colonial e todos os valores brasileiros, para reivindicar seu status europeu (FRANCO, 2008, p. 17-18).

Assim sendo, o autor conclui que o desejo pelo prestígio europeu abriu as portas para a entrada e aceitação do vocabulário europeu (principalmente francês) na língua portuguesa no Rio de Janeiro.

Enfim, evidenciamos alguns dos mais recentes trabalhos que trataram a interface entre léxico e literatura, para mostrar de quais formas têm sido feitas as pesquisas nesse âmbito. A seção a seguir buscará exemplificar como é possível trabalhar com essa interface, levando em consideração os postulados acima elencados.

\section{Exemplos de análise lexical em $O$ Púcaro Búlgaro de Campos de Carvalho}

Walter Campos de Carvalho é um autor literário brasileiro nascido em 1916 na cidade de Uberaba, e morto em 1998. Escreveu seis obras entre 1941 e 1964, dentre as quais quatro foram reeditadas e publicadas em sua Obra Reunida (CARVALHO, 2002): A Lua vem da Ásia, Vaca de Nariz Sutil, A Chuva Imóvel e O Púcaro Búlgaro. As duas outras, intituladas Banda Forra e Tribo, foram as primeiras do autor e são renegadas por ele mesmo.

Seus escritos possuem em comum o teor humorístico e transgressor. São obras que contemplam a falta de lógica e racionalidade, questões amplamente renunciadas pelo escritor, que busca transgredir e afastar-se delas a todo custo em suas produções. Assim, 
todos os aspectos sociais, políticos e culturais considerados lógicos e racionais são deixados de lado em sua Obra Reunida, e suas obras abrem margem para o universo contrário: ilógico, irreal, irracional e transgressor. Isso é refletido nas análises já empreendidas por pesquisadores de sua obra, que possuem dificuldade em encontrar o estilo literário que o autor emprega. Ainda assim, consentiu-se considerá-lo um surrealista, apesar da distância temporal entre o auge desse movimento e o da produção de Campos de Carvalho.

De modo geral, pode-se afirmar que Campos de Carvalho traz à tona a denúncia do que é a Verdade (ou a Normalidade). Equipado de ironia, humor, transgressão e renúncia, este autor cria um mundo, o qual funciona segundo suas próprias regras. Neste mundo, é difícil distinguir o que existe e o que não existe. Em O Púcaro Búlgaro, por exemplo, a loucura é normal, e o normal é a loucura. Dito de outro modo, em $O$ Púcaro Búlgaro, esbarra-se na loucura e no nonsense a todo momento, e estas características são os pilares da obra.

Como era de se esperar, toda a renúncia social e histórica se reflete na linguagem utilizada pelo autor, posto que, como já elencamos anteriormente, consideramos que língua e sociedade são sistemas que se complementam. É importante ressaltar, no entanto, que a transgressão social do autor não se configura como uma transgressão também no plano da linguagem, visto que a linguagem carvaliana utiliza expressivamente os mecanismos já disponíveis para produção de sentido e inovação linguística. Sua criatividade é, portanto, uma inteligente e sábia utilização dos recursos linguísticos existentes.

O Púcaro Búlgaro, por sua vez, escrita em 1964 em formato de diário de bordo, conta, de maneira geral, o planejamento do personagem Hilário em organizar uma expedição à Bulgária, cuja finalidade é atestar a existência deste país e, em especial, dos púcaros búlgaros. Essa expedição conta com outros personagens, que ajudam o narrador a alcançar sua empreitada. De maneira geral, pode-se afirmar que esse romance é o mais humorístico do escritor uberabense. Suas três obras anteriores, apesar de também possuírem tom de comédia e absurdo, ainda carregam um pessimismo e uma denúncia forte contra os sistemas normativos do mundo. Contudo, isso não foi observado em $O$ Púcaro Búlgaro.

De fato, o objetivo de ser um ponto fora da curva, por assim dizer, ainda rege a narrativa. Por outro lado, pode-se afirmar que essa obra é caracterizada por possuir um maior esclarecimento, por parte do escritor, a respeito da sua rebeldia. Dito de outro modo, Campos de Carvalho parece ter percebido que adotar uma postura subversiva com relação ao mundo não faria com que esse mudasse nem reconhecesse os excêntricos ponto que fica evidente no último capítulo de $A$ lua vem da Ásia. Essa percepção fez com que ele amadurecesse sua escrita, evidenciando em seu último romance um protagonista que despreza a sociedade com um humor elevado ao extremo, ironizando todas as organizações, dogmas, regras e grupos sociais.

O romance, portanto, será constituído de um jogo entre sonho e realidade. Pelo fato de Hilário, o narrador-protagonista, encarar todas as situações - por mais absurdas que sejam - com extrema naturalidade, o leitor passa a duvidar e tentar separar o que é fantasioso do que não o é.

Assim sendo, os exemplos de análise que seguirão tentarão dar conta dessa característica peculiar que Campos de Carvalho aplicou na construção d'O Púcaro. Tendo como centro a criatividade do autor, exporemos algumas análises de passagens da obra, 
de forma a exemplificar o uso único que o escritor empregou em questões como a construção do enredo e da lógica do livro.

Sendo assim, iniciaremos nossas análises pelos processos morfológicos de produtividade lexical com a seguinte passagem:

(01) Mesmo que ficasse um dia definitivamente demonstrada a inexistência da Bulgária, ou das Bulgárias, ainda assim continuariam a existir búlgaros - do mesmo modo como existem lunáticos que nunca foram e jamais irão à Lua (CARVALHO, 2002, p. 343).

Neste fragmento, a palavra "lunático" carrega consigo o traço semântico "da lua", isto é, de algo que provém da lua. Ainda assim, observamos que Campos de Carvalho utiliza o referido traço semântico ligado a seres humanos, isto é, lunático seria algo ou alguém que provém da lua. No entanto, sabemos que isto não existe, pois não há seres de origem lunar. A motivação do autor se deve ao sufixo "-ático", que, dentre outras funções, forma adjetivos com o significado "relativo a", em semelhança a "midiático" (relativo à mídia) e "sintático" (relativo à sintaxe). Essa seria uma possível análise.

No entanto, podemos enxergar além dessa simples questão e olhar mais de perto para a lógica do escritor. Ele percebeu ser possível formar a unidade "lunático", e ela ter o sentido explicado acima devido ao acréscimo do sufixo, mesmo sendo comprovadamente impossível a existência desse sentido no mundo real (não há seres de origem lunar). Ou seja, a língua permite formar uma palavra cuja combinação não fere qualquer regra ou norma linguística, mas fere uma norma social e lógica do mundo extralinguístico. Aplicando essa lógica ao enredo de O Púcaro Búlgaro, o qual gira em torno de comprovar a existência da Bulgária, o personagem percebe que, mesmo que tal país não exista (realidade extralinguística), é possível que existam búlgaros, já que a língua permite a existência dessa palavra, a qual designa "relativo a Bulgária". Trata-se, portanto, de um jogo lógico entre duas construções linguísticas que possuem o mesmo significado, qual seja, "relativo à".

Uma análise como essa deve levar em conta o estudo aprofundado das características do autor. Como explicitado na seção 2.2, o sentido das unidades lexicais retiradas de uma obra literária não deve ser considerado em relação ao contexto fora da obra, mas inteiramente em relação ao contexto do enredo e da produção de sentido da obra. Esse aspecto teórico torna possível a análise acima, que segue a lógica da obra.

Vejamos outro exemplo:

(02) O vento fustiga as velas, corre-me pela nuca e pelos cabelos, e volta para o mar alto. Aqui em cima, do alto da Gávea, as estrelas cintilam mais perto (CARVALHO, 2002, p. 318).

Esse trecho inicia o enredo da história a ser contada. Após os capítulos iniciais, o registro do que se passou (ou não se passou, conforme o narrador) em forma de diário começa com a passagem acima. Neste fragmento, o vocabulário escolhido por Campos de Carvalho para iniciar o enredo deixa o leitor, de certa forma, confuso. Os capítulos anteriores a esse explicam que ocorreu uma expedição à Bulgária, na qual o narrador Hilário foi o líder. Assim, ao ler o excerto, o leitor é levado a crer que os personagens já estão no navio, visto que a "vela" seria o pedaço de tecido que leva a embarcação para frente, "mar alto" o local onde estão posicionados geograficamente no oceano, sem proximidade com as costas, e "Gávea" seria o local mais alto, em um navio, perto dos 
mastros, utilizado para enxergar adiante com luneta ou outro instrumento, segundo o Dicionário Caldas Aulete (CALDAS AULETE, 1964).

No entanto, essa suposição se prova falsa, quando o leitor percebe que o narrador está, na verdade, em seu quarto, escrevendo no diário, iluminado por "velas", próximo ao "mar alto" e no alto da "Gávea", bairro do Rio de Janeiro. Esse efeito de sentido provocado por Campos de Carvalho se deve à polissemia das unidades escolhidas para compor a passagem destacada acima, introduzindo o leitor no jogo de palavras por meio do qual o texto é construído.

(03) Se é que a Bulgária é mesmo nome de lugar e não uma maneira de expedir alguma coisa: expedição à Bulgária, como quem diz à francesa, ou à inglesa, ou simplesmente à milanesa (CARVALHO, 2002, p. 349).

Nesse trecho, o autor nos dá uma pista sobre o teor da obra que, quase sempre, passa despercebido. Ao afirmar que uma "expedição à Bulgária" pode ser uma maneira de se expedir alguma coisa, ao invés de ser o destino para o qual a expedição irá, ele mais uma vez instaura a possibilidade de a expedição sobre a qual o livro se apoia ser, na verdade, uma farsa. Tal cenário se torna ainda mais possível ao notarmos que, algumas páginas antes, um dos personagens afirmou: "o que se convencionou chamar a Bulgária é sobretudo um estado de espírito" (CARVALHO, 2002, p. 343). Assim, uma "expedição à Bulgária" nada mais seria do que uma expedição sem lógica, impossível, absurda, visto que a Bulgária, no mundo da narrativa, não existe.

Toda essa teoria se desenvolve através da expressão "à alguma coisa", cujo significado é "ao modo de/a maneira de". Considerando, então, que a Bulgária é um local inexistente, ou sobretudo um estado de espírito, como a própria narrativa sugere, uma "expedição à Bulgária" seria uma expedição realmente fantasiosa, inexistente. E é justamente isso que se desenrola no romance: os personagens fazem planos expedicionários, vivem suas situações cotidianas mais absurdas e improváveis, mas não realizam viagem alguma.

Nesse sentido, a própria construção dos personagens pode ser vista como absurda, impossível e humorística, sobretudo no nível lexical. De fato, Campos de Carvalho demonstra, a todo momento, utilizar a linguagem em favor do objetivo de sua obra, lançando mão dos recursos linguísticos a fim de criar uma narrativa expressiva. $O$ personagem Pernacchio é uma evidência disso. Diz o narrador: "um tal de Pernacchio, que morou muitos anos ao lado da Torre de Pisa [...]. Pareceu-me um pouco inclinado para a esquerda, mas como não tenho preconceitos políticos [...] afirmei-lhe que seria bem-vindo" (CARVALHO, 2002, p. 331). Na apresentação dessa personagem, podemos notar a polissemia das palavras "inclinado" e "esquerda". O sentido da primeira palavra tanto pode ser "desviado da direção vertical" (CALDAS AULETE, 1964, p. 2146) quanto "Propenso, disposto, afeiçoado" (CALDAS AULETE, 1964, p. 2146). A segunda, por sua vez, tanto pode significar o lado esquerdo quanto a posição política do personagem.

Outro exemplo dessa construção humorística ocorre com o personagem Expedito: "um Expedito não sei do quê, que pelo nome foi imediatamente incorporado à expedição" (CARVALHO, 2002, p. 332). Mais uma vez, vemos o jogo lexical, recurso utilizado por Campos de Carvalho para gerar criatividade e humor à sua obra. O trecho, repleto de ironia e humor, pode ser interpretado pelo fato de o personagem Expedito possuir o nome do objetivo dos outros personagens, qual seja, realizar uma expedição. Assim, para atingir 
tal objetivo, incorpora-se um personagem cujo nome exprime exatamente a ideia que se pretende atingir.

A terceira análise se dará sobre a palavra "Partida". Essa unidade lexical é a que intitula o último capítulo de $O$ Púcaro Búlgaro, quando os leitores esperam que, finalmente, após tantos acontecimentos e preparação, os personagens irão partir rumo à Bulgária. No entanto, o capítulo é construído por meio de um diálogo entre três personagens, que estão jogando uma partida de poker. A "Partida" a que se refere o título do capítulo é, portanto, um jogo de cartas, e não a ida para o país que se objetivou descobrir.

A quebra de expectativa gerada se apoia, novamente, sobre a polissemia de uma unidade lexical, dessa vez a unidade "Partida". Entretanto, é possível analisar o fato de a escolha pelo jogo de Poker não ter sido arbitrária. Este jogo é caracterizado por ser uma competição na qual se deve utilizar o blefe, a mentira e a manipulação. Por meio da enganação, os jogadores manipulam uns aos outros, tentando fazer o outro crer que as cartas dele são melhores. Assim, a manipulação ocorre quando um jogador joga conforme as vontades do outro, sem ter a percepção disso. O poker é uma disputa que não se joga sozinho, na qual o bom jogador é aquele que joga com os outros, manipulando-os, fazendo-os crer que estão no controle da situação quando, na verdade, estão sendo controlados.

Assim, a polissemia da unidade lexical "Partida", ao final, revela ao leitor a única verdade de $O$ Púcaro Búlgaro: ele foi, desde o princípio, manipulado pelo autor da obra, tendo que renunciar, também, aos 'contratos' que estabelecemos diariamente com o mundo, para que pudesse compreender a totalidade d' $O$ Púcaro. No entanto, percebe-se, ao final, que se tratou apenas de uma manipulação de quem 'dava as cartas', isto é, o narrador, como num jogo de poker.

\section{5. À guisa de conclusão}

Buscou-se, com este artigo, expor as principais formas de trabalhar com o texto literário, por meio do léxico. O objetivo era exemplificar, através de uma obra literária, como o trabalho na interface léxico-literária ocorre. Para isso, foi preciso elencar alguns pressupostos teóricos e revisar trabalhos recentes que tratam essa relação.

Assim, o trabalho com o léxico, tendo como corpus o texto literário, pode ser extremamente produtivo, tanto por meio da lexicologia, trabalhando questões como a formação de palavras, os neologismos e o significado das unidades lexicais, quanto através da lexicografia, produzindo dicionários e vocabulários específicos de autores, obras ou escolas literárias.

Conclui-se, também, que $O$ Púcaro Búlgaro é uma obra construída em um mundo particular, com regras, atitudes, pensamentos e acontecimentos próprios. Dessa forma, o "diferente" tem seu espaço na obra. Isso, consequentemente, é marcado pela falta de sentido e senso social, manifestados na presença da loucura, do nonsense e da renúncia. Dessa forma, Campos de Carvalho faz um "jogo" com as questões sociais e políticas que regem o mundo, alterando-o completamente. Por sua vez, a linguagem acompanha essas mudanças e acaba sendo utilizada da mesma forma: com sentidos particulares, próprios da obra. Por isso, uma análise no nível lexical em $O$ Púcaro Búlgaro se tornaria extremamente proveitosa, principalmente em se tratando de conferir significado à obra. 


\section{REFERÊNCIAS}

ALVES, G. O estudo dos compostos e fraseologismos criados por João Cabral de Melo Neto: proposta de estudo da coindexicação semântica. 2013. 273 f. Tese (Doutorado em Linguística e Língua Portuguesa) - Faculdade de Ciências e Letras, Universidade Estadual Paulista, Araraquara, 2013.

ÁVILA, M. V. D.; MARTINS, E. S. O léxico indianista em José de Alencar. Vertentes, v. 1, p. 233-245, 2008.

BARBOSA, M. A. Da neologia à neologia na literatura. In: OLIVEIRA, A. M. P. de; ISQUERDO, A. N. As ciências do léxico: lexicologia, lexicografia, terminologia. 2. ed. Campo Grande: Editora da UFMS, 2001. p. 33-51.

BIDERMAN, M. T. C. Conceito linguístico de palavra. In: BASÍLIO, M. (Org.). $A$ delimitação de unidades lexicais. Rio de Janeiro: Grypho, 1999. p. 81-97.

Teoria linguística: linguística quantitativa e computacional. Rio de Janeiro: Livros Técnicos e Científicos, 1978.

CAldas AUlete, F. J. Dicionário Contemporâneo da Língua Portuguesa. 5. ed. Rio de Janeiro: Delta, 1964.

CARVALHO, C. de. O Púcaro Búlgaro. In: CARVALHO, C. de. Obra Reunida. 3. ed. Rio de Janeiro: José Olympio, 2002. p. 307-382.

DUBOIS, J. et al. Dicionário de Linguística. 2. ed. São Paulo: Cultrix, 2014.

FRANCO, P. C. B. O léxico da "Belle Époque” na obra de João do Rio. 2008. 199 f. Tese (Mestrado em Linguística e Língua Portuguesa) - Faculdade de Ciências e Letras, Universidade Estadual Paulista, Araraquara, 2008.

MARTINS, E. S. A neologia na literatura: a criação milloriana. In: ISQUERDO, A. N.; KRIEGER, M. da. G. As ciências do léxico: lexicologia, lexicografia, terminologia. v. 2. Campo Grande: Editora da UFMS, 2004. p. 53-63.

O neologismo cruzesousiano e o simbolismo. In: ISQUERDO, A. N.; ALVES, I. M. (Org.). As ciências do léxico: lexicologia, lexicografia, terminologia. v. 3. Campo Grande: Editora da UFMS; São Paulo: Humanitas, 2007. p. 65-75.

MARTINS, N. S. O léxico de João Guimarães Rosa. 3. ed. São Paulo: Editora da Universidade de São Paulo, 2008.

PROENÇA FILHO, D. A linguagem literária. 8. ed. São Paulo: Ática, 2007.

Recebido em: 15/08/2016

Aprovado em: 29/05/2017 